\title{
EFEKTY ENERGETYCZNE WYBRANYCH WARIANTÓW TERMOMODERNIZACJI BUDYNKÓW MIESZKALNYCH
}

\begin{abstract}
$\mathrm{W}$ artykule przeanalizowano możliwości zmniejszenia zużycia energii w grupie budynków mieszkalnych na przykładzie rzeczywistego kompleksu budynków należących do spółdzielni mieszkaniowej z lat 80-tych, zasilanej z lokalnej kotłowni węglowej. Istnieją różne rozwiązania, dzięki którym można osiągnąć założony cel. W niniejszym opracowaniu rozważono 4 warianty, z których pierwszy obejmuje pełną termomodernizację budynków (ściany zewnętrzne, stropodachy, stolarka okienna w częściach wspólnych). W wariancie 2 , oprócz rozwiązań zaproponowanych w wariancie 1, rozważono wymianę instalacji wewnętrznej c.o. i c.w.u. Wariant 3 zawiera dodatkowo propozycję budowy nowej kotłowni gazowej. Ostatni wariant jest rozszerzeniem wariantu 3. Znajduje się w nim analiza wykorzystania kolektorów słonecznych na przygotowanie ciepłej wody użytkowej. W celu przygotowania bilansu energetycznego efektów termomodernizacji z wykorzystaniem odnawialnych źródeł energii, zamodelowano budynki w programie Audytor OZC 6.5. Pro. Dodatkowo skorzystano z programu RETScreen 4, który pozwolił dobrać odpowiednią wielkość instalacji kolektorów słonecznych. Otrzymane wyniki zostały następnie zestawione i przeanalizowane. Głównym wnioskiem jaki otrzymano, jest bardzo korzystny wpływ termomodernizacji budynków na zmniejszenie ich zapotrzebowania na energię. W obiektach kilkudziesięcioletnich, wystarczy wykonać odpowiednią warstwę izolacji na przegrodach zewnętrznych aby zmniejszyć to zapotrzebowanie o 40-50\%. W celu uzyskania większych efektów energetycznych, należy wykonać dodatkowe zadania modernizacyjne. Należy jednak pamiętać, że głęboka termomodernizacja, wykonana na grupie budynków, a nie na jednym obiekcie, jest najbardziej korzystnym ze wszystkich rozwiązań.
\end{abstract}

Słowa kluczowe: efektywność energetyczna, odnawialne źródła energii, audyt energetyczny, ocieplenie budynku, budownictwo wielorodzinne

\section{Wprowadzenie}

Zapotrzebowanie na energię wciąż wzrasta, w przeciwieństwie do zasobów paliw kopalnych, które kurczą się z każdym rokiem. Efektem tego jest rosnące zanieczyszczenie środowiska, a także koszty wytwarzania i przesyłu energii.

\footnotetext{
${ }^{1}$ Kamil Różycki, Politechnika Warszawska, Zakład Chłodnictwa i Energetyki Budynku, ul. Nowowiejska 21/25, 00-665 Warszawa; tel. 500752994; krozycki@nape.pl
} 
Rozwiązaniem tych problemów może być zwiększenie efektywności wykorzystania energii oraz zmniejszenie jej zużycia. Jak wynika z danych GUS-u [1], w Polsce w 2013 roku, największe zużycie energii występowało w sektorze gospodarstw domowych stanowiąc $33 \%$ całości. W przedstawionym sektorze w 2012 roku, aż 68,8\% energii było potrzebne na cele ogrzewania pomieszczeń. Kolejną pozycję, z wynikiem $14,8 \%$, stanowiło zużycie energii niezbędnej do przygotowania ciepłej wody użytkowej [1].

Wyznaczając zapotrzebowanie na energię dla budynku należy wykonać bilans energetyczny obiektu, w którym zestawione zostaną zarówno zyski, jak i straty. Te pierwsze pochodzą przede wszystkim z energii promieniowania słonecznego, która przedostaje się do budynku przez przegrody przezroczyste. Nie bez znaczenia są również zyski od ludzi i urządzeń znajdujących się wewnątrz pomieszczeń. W budynkach tradycyjnych energia jest tracona na drodze przenikania przez przegrody przezroczyste (okna $15-25 \%$ ), nieprzezroczyste (ściany 20-30\%, dach 10-15\%), piwnicę 3-6\% oraz przez wentylację (30-40\%) [2]. Podstawowymi czynnikami mającymi wpływ na rozkład zużycia energii przez budynek sa przede wszystkim: lokalizacja i otoczenie budynku, warunki klimatyczne, dostępność energii promieniowania słonecznego, kształt budynku, rozmieszczenie pomieszczeń, a także sposób użytkowania przez mieszkańców.

Według danych Eurostatu [3] w Polsce w 2014 roku 44,7\% ludności mieszkało w budynkach wielorodzinnych (przykładowa grupa takich budynków została poddana dokładniejszej analizie w dalszej części artykułu). W przypadku takich budynków straty ciepła wynoszą: $28 \%$ przez okna, 25\% przez ściany, $39 \%$ przez wentylację, 4\% przez stropodach oraz grunt [4]. Przedstawione wartości są wartościami uśrednionymi. Istnieją różne analityczne rozwiązania pozwalające zamodelować budynek, a następnie dobrać takie rozwiązania, które w optymalny sposób pozwolą na zmniejszenie jego zapotrzebowania na energię. Jednym z rozwiązań, które może wpłynąc korzystnie na ekonomiczną stronę przedsięwzięcia jest wykonanie analizy, a następnie modernizacji nie dla jednego budynku lecz dla całej ich grupy, najlepiej znajdujących się w bliskiej odległości od siebie. W niniejszym artykule przedstawiono propozycję termomodernizacji grupy budynków, która należy do spółdzielni mieszkaniowej i która znajduje się na terenie województwa mazowieckiego.

\section{Opis stanu istniejącego badanej grupy budynków}

Analizowane budynki (Rys.1-4) są budynkami rzeczywistymi. W skład grupy budynków wchodzą 4 obiekty 3-kondygnacyjne, całkowicie podpiwniczone wybudowane w latach 1982-1985, 1 obiekt 2-kondygnacyjny, częściowo podpiwniczony z roku 1967 oraz obiekt parterowy, niepodpiwniczony z roku 1965. Wszystkie obiekty poza ostatnim są wykonane w technologii betonowych elementów prefabrykowanych. W budynkach ściany szczytowe mają grubość $27 \mathrm{~cm}$ (w dwóch z nich wykonano docieplenie $3 \mathrm{~cm}$ styropianu), a pozostałe 


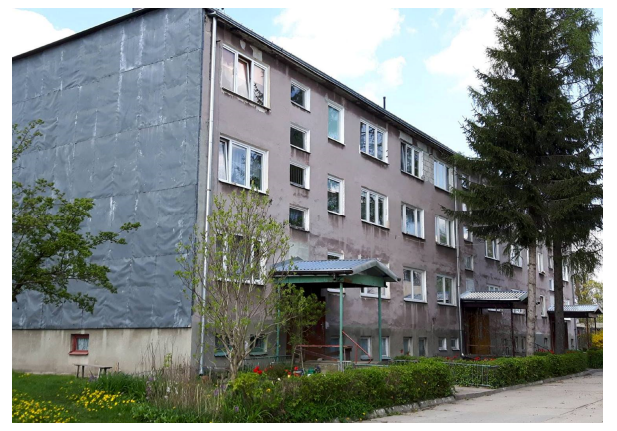

Rys. 1. Budynek 3-kondygnacyjny (fotografia własna) Fig. 1. 3-storey building (own photography)

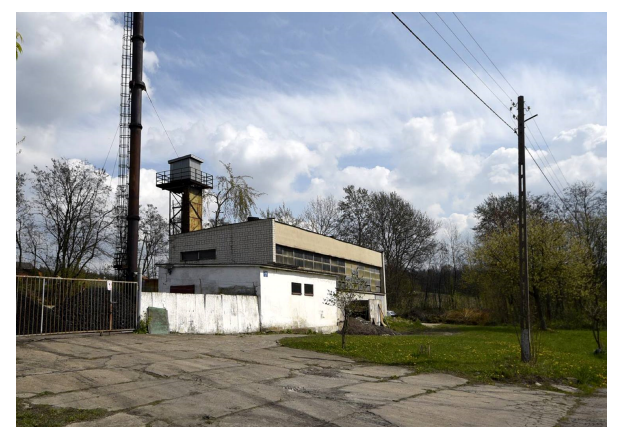

Rys. 3. Kotłownia (fotografia własna)

Fig. 3. Boiler house (own photography)

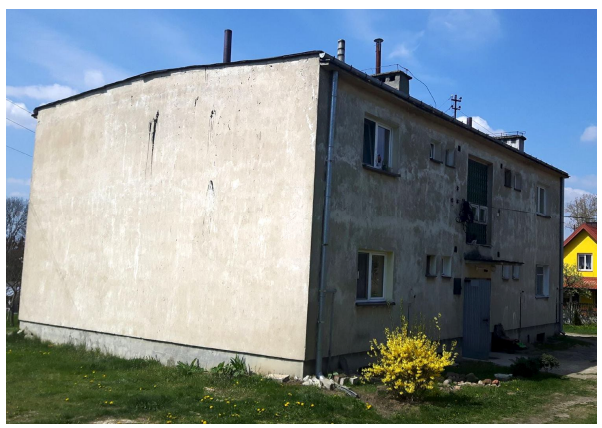

Rys. 2. Budynek 2-kondygnacyjny (fotografia własna) Fig. 2. 2-storey building (own photography)

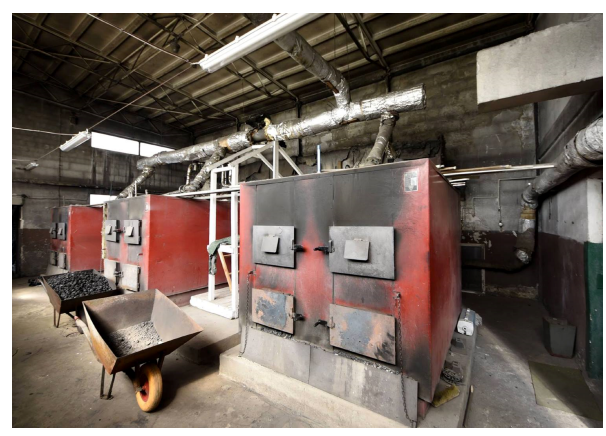

Rys. 4. Kotłownia (fotografia własna)

Fig. 4. Coal boilers (own photography)

ściany zewnętrzne $24 \mathrm{~cm}$. W większości przypadków okna w częściach mieszkalnych zostały już wymienione, należy jednak wymienić okna w częściach wspólnych (klatki schodowe). Budynek parterowy jest wykonany z drewnianych bali.

Źródłem ciepła dla badanej grupy budynków jest instalacja centralnego ogrzewania (c.o.), dla której czynnikiem grzewczym jest woda pogrzana w osiedlowej niskotemperaturowej kotłowni węglowej wykonanej w latach 80-tych. Ciepła woda użytkowa (c.w.u.) dla 4 największych budynków jest podgrzewana w 4 pojemnościowych podgrzewaczach, każdy o pojemności 1600 litrów. W pozostałych budynkach przygotowanie c.w.u. odbywa się indywidualnie w elektrycznych lub gazowych podgrzewaczach.

\section{Metodyka i wyniki badań}

W celu zmniejszenia zapotrzebowania budynku na energię należy zastanowić się nad możliwymi wariantami modernizacji, a następnie rozpatrzyć, które z rozwiązań spełni określone oczekiwania. 
Aby wykonać obliczenia energetyczne dla badanego przypadku, należało rozpocząć pracę od stworzenia modelu komputerowego każdego z budynków. Dla celów niniejszej pracy, obliczenia mocy cieplnej systemu grzewczego oraz zużycia energii cieplnej do ogrzewania zostały wyznaczone w programie Audytor OZC 6.5 pro. Obliczenia sezonowego zapotrzebowania budynków w standardowym sezonie grzewczym wykonano na podstawie normy PN-EN 13790 „Energetyczne właściwości użytkowe budynków. Obliczanie zużycia energii na potrzeby ogrzewania i chłodzenia”. Moc obliczono na podstawie normy PN-EN 12831 „Instalacje ogrzewcze w budynkach. Metoda obliczania projektowego obciążenia cieplnego."

Zaproponowano 4 warianty, z których każdy kolejny zawiera prace z poprzedniego poszerzone o dodatkowe działanie. Wariant 1 dotyczy termomodernizacji każdego z budynków, tj. ocieplenie ścian, stropodachu, wymiana stolarki okiennej w częściach wspólnych. Wybrano takie rozwiązania, które spełniają „Warunki Techniczne” [5] obowiązujące od 2017 r. Wariant 2 jest poszerzony o wymianę instalacji c.o. i c.w.u. Wariant 3 przewiduje budowę nowej kotłowni gazowej. Wariant 4 zawiera instalację kolektorów słonecznych, których zadaniem będzie pokrycie części potrzeb na przygotowanie c.w.u.

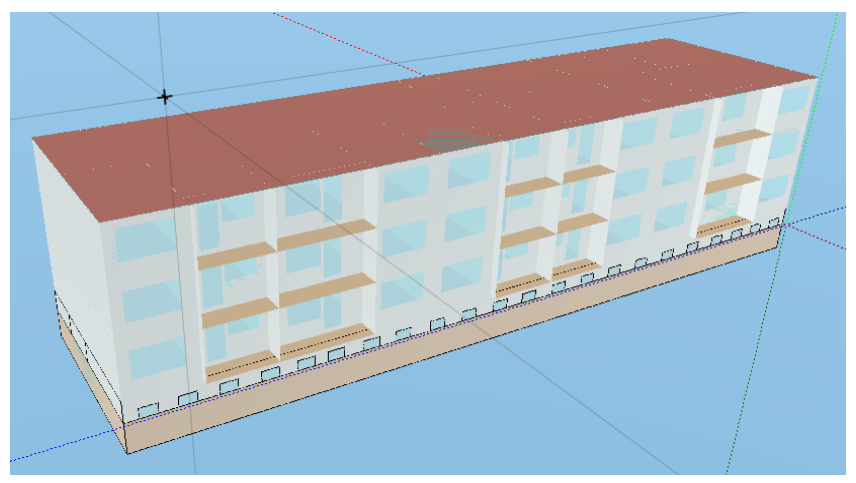

Rys. 5. Budynek 3-kondygnacyjny zamodelowany w programie Audytor OZC 6.5. Pro

Fig. 5. 3-storey building modeled in the Auditor OZC 6.5. Pro

\section{Analiza wyników}

Najważniejsze z uzyskanych wyników zostały zestawione w tabeli 1. Wartości dotyczące zapotrzebowania na ciepłą wodę użytkową zostały wyznaczone za pomocą wzorów zawartych w odpowiednim Rozporządzeniu [6]. 
Tabela 1. Charakterystyka energetyczna grupy budynków

Table 1 . The energy performance of the group of buildings

\begin{tabular}{|l|c|c|c|c|c|}
\hline \multicolumn{1}{|c|}{$\begin{array}{c}\text { Charakterystyka energetyczna } \\
\text { grupy budynków }\end{array}$} & \multirow{2}{*}{$\begin{array}{c}\text { stan ist- } \\
\text { niejący }\end{array}$} & \multicolumn{4}{|c|}{ stan po termomodernizacji } \\
\cline { 4 - 6 } & 495,6 & 284,2 & 284,2 & 284,2 & 284,2 \\
\hline $\begin{array}{l}\text { Obliczeniowa moc cieplna systemu } \\
\text { grzewczego [kW] }\end{array}$ & 287,2 & 287,2 & 246,2 & 181,9 & 181,9 \\
\hline $\begin{array}{l}\text { Obliczeniowa moc cieplna (max) na } \\
\text { przygotowanie c.w.u. [kW] }\end{array}$ & 8853,3 & 4623,8 & 3821,1 & 2614,4 & 2614,4 \\
\hline $\begin{array}{l}\text { Roczne obliczeniowe zużycie energii } \\
\text { do ogrzewania budynku* [GJ/rok] }\end{array}$ & 1197,1 & 1197,1 & 1026,1 & 757,9 & 558,9 \\
\hline $\begin{array}{l}\text { Roczne obliczeniowe zużycie energii } \\
\text { do przygotowania c.w.u* [GJ/rok] }\end{array}$ & 10050,4 & 5820,9 & 4847,2 & 3372,3 & 3173,3 \\
\hline $\begin{array}{l}\text { Roczne obliczeniowe zużycie energii } \\
\text { razem* [GJ/rok] }\end{array}$ & 0 & 42,1 & 52,8 & 66,4 & 68,4 \\
\hline Zaoszczędzona energia [\%] & & & & \\
\hline
\end{tabular}

*z uwzględnieniem sprawności - energia końcowa

\subsection{Wariant 1}

Wyniki obliczeń, wskazują na to, że zaproponowana termomodernizacja budynków jest bardzo efektywna energetycznie. W stanie istniejącym, budynki są w zdecydowanej mierze niedocieplone. $\mathrm{W}$ wariancie 1 dla przegród budynków zaproponowano takie rozwiązania, aby spełnić wymagania określone w „Warunkach Technicznych” [5]. Ściany zewnętrzne są docieplone $11 \mathrm{~cm}$ styropianu o współczynniku przewodzenia ciepła $\lambda$ na poziomie $0,031 \mathrm{~W} / \mathrm{mK}$. Dzięki temu rozwiązaniu współczynnik przenikania ciepła $U$ dla ścian zewnętrznych zmniejsza się z 1,3 do $0,23 \mathrm{~W} / \mathrm{m}^{2} \mathrm{~K}$. Współczynnik U dla stropodachu wentylowanego, po dociepleniu $20 \mathrm{~cm}$ granulatu $\mathrm{z}$ wełny mineralnej o $\lambda=0,042 \mathrm{~W} / \mathrm{mK}$, wynosi $0,18 \mathrm{~W} / \mathrm{m}^{2} \mathrm{~K}\left(1,13 \mathrm{~W} / \mathrm{m}^{2} \mathrm{~K}-\right.$ stan istniejący). W budynkach dodatkowo zaproponowano wymianę okien w częściach wspólnych, czyli na klatkach schodowych na takie o współczynniku $\mathrm{U}=1,1 \mathrm{~W} / \mathrm{m}^{2} \mathrm{~K}$ (obecnie $\left.3,5 \mathrm{~W} / \mathrm{m}^{2} \mathrm{~K}\right)$.

Termomodernizacja wszystkich budynków, doprowadzając je do wymagań technicznych WT 2017, zmniejsza zapotrzebowania na energię o 42,1\%.

\subsection{Wariant 2}

Wariant 2, oprócz rozwiązań zaproponowanych w wariancie 1, rozważono wymianę instalacji wewnętrznej c.o. i c.w.u. Przedsięwzięcie to obejmuje swoim zakresem wymianę wszystkich elementów obu instalacji. Sprawność systemu grzewczego wzrasta z 43 do $51 \%$. W przypadku systemu przygotowania c.w.u. wartość ta zmienia się z 39 na 46\%. Realizacja wariantu 2 przynosi zmniejszenie zapotrzebowania na energię o $52,8 \% \mathrm{w}$ stosunku do stanu istniejącego. 


\subsection{Wariant 3}

Między innymi ze względu na wzrastające zanieczyszczenie środowiska, zaleca się, aby wymieniając źródło ciepła rozważyć bardziej ekologiczne rozwiązanie niż istniejące $w$ obecnym stanie. Przy termomodernizacji budynków zasilanych z lokalnych kotłowni węglowych lub indywidualnych konwencjonalnych źródeł ciepła, często analizuje się możliwość przyłączenia do miejskiej sieci ciepłowniczej. Gdy taka możliwość nie istnieje, należy wybrać inne rozwiązanie. Podobnie jest $\mathrm{w}$ analizowanym przykładzie, dlatego zaproponowano budowę nowej kotłowni gazowej. Sprawność całkowita takiego systemu wzrasta z 51 na $75 \%$, a oszczędność energii w stosunku do stanu istniejącego wynosi $66,4 \%$.

\subsection{Wariant 4}

W ostatnim wariancie zaproponowano, aby dodatkowo zastosować kolektory słoneczne, które wspomogą system przygotowania c.w.u. Obliczenia zostały wykonane w programie RETScreen 4. Po wprowadzeniu do programu przykładowego kolektora słonecznego nachylonego pod kątem $35^{\circ}$, a także sprawności wytwarzania ciepła w kolektorze $(70 \%)$ oraz przesyłu ciepła $(85 \%)$ oraz pozostałych strat, wybraniu najbliższej lokalizacji z dostępnej w programie bazie stacji meteorologicznych, uzyskano wyniki. System dobrano tak, aby kolektory pokryły około $30 \%$ rocznych potrzeb na energię na cele przygotowania c.w.u. we wszystkich budynkach łącznie. Łączna liczba kolektorów słonecznych wynosi 90, a całkowita powierzchnia czynna absorbera to $208,8 \mathrm{~m}^{2}$. Dzięki takiemu rozwiązaniu, połączonemu z poprzednimi wariantami, można łącznie zmniejszyć zużycie energii o $68,4 \%$.

W opracowaniu podjęto również próbę określenia kosztów i efektów finansowych dla rozpatrywanych wariantów. Wyniki otrzymano analizując rynek i wybierając odpowiednie dostępne rozwiązania. Dokładne dane nie będą jednak opisane w niniejszym opracowaniu. Należy jednak zaznaczyć, że kompleksowa termomodernizacja wraz z wykonaniem jej w kilku budynkach jednocześnie obniża koszty jednostkowe w stosunku do modernizacji budynków osobno. Wyniki zestawiono $\mathrm{w}$ tabeli 2 . Zauważa się, że pomimo tego, że w wariancie pierwszym oszczędności energii są najwyższe, to czas zwrotu inwestycji jest najmniejszy.

Tabela 2. Określenie kosztów i efektów finansowych rozpatrywanych wariantów

Table 2. Determination of the cost and financial effects of the presented variants

\begin{tabular}{|c|c|c|c|c|}
\hline $\begin{array}{c}\text { Wariant przed- } \\
\text { sięwzięcia termo- } \\
\text { modernizacyjnego }\end{array}$ & $\begin{array}{c}\text { Planowane } \\
\text { koszty } \\
\text { [mln. zl] }\end{array}$ & $\begin{array}{c}\text { Roczna oszczędność } \\
\text { kosztów energii } \\
\text { [tys. zl] *** }\end{array}$ & $\begin{array}{c}\text { Procentowa } \\
\text { oszczędnośćc } \\
\text { energii [\%] }\end{array}$ & $\begin{array}{c}\text { Czas zwrotu } \\
\text { [SPBT] }\end{array}$ \\
\hline W1 & 1,2 & 101,5 & 42,1 & 11,7 \\
\hline W2 & 1,9 & 124,9 & 51,8 & 15,6 \\
\hline W3 & $2,2^{*}$ & 61,9 & 66,4 & 35,3 \\
\hline W4 & $2,8^{*}$ & 71,1 & 68,4 & 38,9 \\
\hline
\end{tabular}

*bez kosztów przyłącza

** różnica między kosztami energii przed wykonaniem wariantu, a kosztami po jego wykonaniu 


\section{Wnioski}

Planując przeprowadzenie termomodernizacji budynku warto wcześniej zastanowić się nad wykonaniem dodatkowych prac związanych ze zwiększeniem efektywności energetycznej obiektu. Szczególnie korzystnym rozwiązaniem wydaje się wykonanie działań nie na jednym, lecz jednocześnie na grupie budynków. Warto jednak zauważyć, że w pierwszej kolejności należy wykonać pełną termomodernizację przegród budynku. Wykonując takie działania na budynkach z lat 80-tych czy starszych, doprowadzając je do obowiązujących standardów, można zmniejszyć zapotrzebowanie na energię o 40-50\%, a nawet więcej. Dodatkowe czynności, np. zwiększające sprawność systemów grzewczego i przygotowania c.w.u., a także wymiana źródła ciepła dają również zauważalne korzyści. Kompleksowe działania na budynkach kilkudziesięcioletnich, w których i tak należałoby wykonać prace remontowe, pozwalają na zmniejszenie zużycia energii nawet 3-4 krotnie. Wykonując termomodernizację budynku warto również rozważyć zastosowanie odnawialnych źródeł energii. Pomimo tego, że nie zawsze efekty energetyczne są duże, to pojawia się wiele innych korzyści i można się spodziewać, że korzystanie z takich systemów w budownictwie stanie się wkrótce standardem.

Opisane prace sa wykonywane $w$ ramach realizacji projektu DREEAM, finansowanego z programu Horyzont 2020 (http://dreeam.eu/), którego polskim partnerem jest Narodowa Agencja Poszanowania Energii S.A.

\section{Literatura}

[1] Główny Urząd Statystyczny, Efektywność wykorzystania energii w latach 2003-2013, Warszawa 2015: http://stat.gov.pl/obszary-tematyczne/srodowisko-energia/energia /efektywnosc-wykorzystania-energii-w-latach-2003-2013,5,10.html \{dostęp 17.05.2016 r.\}.

[2] Węglarz A.: „Budynki tradycyjne,” materiał ze studiów podyplomowych na Politechnice Warszawskiej, Budownictwo Energooszczędne: Certyfikacja energetyczna, audyt energetyczny i termomodernizacja budynków, 2015.

[3] Eurostat: http://appsso.eurostat.ec.europa.eu/nui/submitViewTableAction.do \{dostęp 17.05.2016 r.\}.

[4] Sarosiek W., Sadowska B., Święcicki A.: Wpływ eksploatacji mieszkań na zużycie energii, Politechnika Białostocka, Katedra Podstaw Budownictwa i Fizyki Budowli, 2002.

[5] Rozporządzenie Ministra Infrastruktury z dnia 12 kwietnia 2002 r. w sprawie warunków technicznych, jakim powinny odpowiadać budynki i ich usytuowanie (Dz. U. z 2013 r. poz. 1409, z późn.zm.2).

[6] Rozporządzenie Ministra Infrastruktury i Rozwoju z dnia 27 lutego 2015 r. w sprawie metodologii wyznaczania charakterystyki energetycznej budynku lub części budynku oraz świadectw charakterystyki energetycznej (Dz.U. 2015 poz. 376). 


\section{ENERGETIC EFFECTS OF SELECTED VARIANTS OF THERMO- MODERNIZATION IN RESIDENTIAL BUILDINGS}

\section{S u m m a r y}

This article examines the possibility of reducing energy consumption in a group of residential buildings on the example of existing complex of buildings from the $80 \mathrm{~s}$ which is supplied from the local coal boiler house. They belong to housing cooperative. There are various solutions for reducing energy demand. This study examines four variants. The 1st, includes a full thermomodernization of buildings (external walls, roofs, windows in the common areas). The 2 nd variant, in addition to the solutions proposed in variant 1 , includes exchange of internal installations of central heating and domestic hot water systems (DHW). The 3 rd variant includes 2 nd variant and exchange of the old coal boiler for the new gas boiler. The last variant includes 3rd variant and installation of solar collectors for preparation of DHW. In order to analyze the energy consumption and effects of energy balance of the thermo-modernization with using renewable sources of energy, the buildings have been modeled in the Audytor OZC 6.5 Pro software. The installation of solar collectors has been selected by using RETScreen 4 software. The results were summarized and analyzed. The main conclusion which was observed is very positive impact of thermal insulation on the building energy demand. The same insulation, when it is made on buildings from the 80 s and older, can reduce energy demand by $40-50 \%$. In order to achieve greater energy effects, his necessary to perform additional tasks of modernization. The best solution is deep thermomodernization made on a group of buildings.

Keywords: energy efficiency, renewable sources of energy, energy audit, building insulation, multi-family housing

Przestano do redakcji: 26.05.2017 r.

Przyjęto do druku: 15.12.2017 r. 